\title{
Temporal relationship between air pollutants and hospital admissions for chronic obstructive pulmonary disease in Hong Kong
}

\author{
Fanny W S Ko, Wilson Tam, Tze Wai Wong, Doris P S Chan, Alvin H Tung, Christopher K W Lai, \\ David S C Hui
}

See end of article for authors' affiliations

Correspondence to: Dr David S C Hui, Department of Medicine and Therapeutics, The Chinese University of Hong Kong, Prince of Wales Hospital, 30-32 Ngan Shing Street, Shatin, New Territories, Hong Kong; dschui@cuhk. edu.hk

Received 5 December 2006 Accepted 4 February 2007 Published Online First 20 February 2007

\begin{abstract}
Aims: To assess any relationship between the levels of ambient air pollutants and hospital admissions for chronic obstructive pulmonary disease (COPD) in Hong Kong.

Methods: A retrospective ecological study was undertaken. Data of daily emergency hospital admissions to 15 major hospitals in Hong Kong for COPD and indices of air pollutants (sulphur dioxide $\left(\mathrm{SO}_{2}\right)$, nitrogen dioxide $\left(\mathrm{NO}_{2}\right)$, ozone $\left(\mathrm{O}_{3}\right)$, particulates with an aerodynamic diameter of $<10 \mu \mathrm{m}\left(\mathrm{PM}_{10}\right)$ and $2.5 \mu \mathrm{m}$ $\left(\mathrm{PM}_{2.5}\right)$ ) and meteorological variables from January 2000 to December 2004 were obtained from several government departments. Analysis was performed using generalised additive models with Poisson distribution, adjusted for the effects of time trend, season, other cyclical factors, temperature and humidity. Autocorrelation and overdispersion were corrected.

Results: Significant associations were found between hospital admissions for COPD with all five air pollutants. Relative risks for admission for every $10 \mu \mathrm{g} / \mathrm{m}^{3}$ increase in $\mathrm{SO}_{2}, \mathrm{NO}_{2}, \mathrm{O}_{3}, \mathrm{PM}_{10}$ and $\mathrm{PM}_{2.5}$ were 1.007, $1.026,1.034,1.024$ and 1.031 , respectively, at a lag day ranging from lag 0 to cumulative lag $0-5$. In a multipollutant model, $\mathrm{O}_{3}, \mathrm{SO}_{2}$ and $\mathrm{PM}_{2.5}$ were significantly associated with increased admissions for COPD. $\mathrm{SO}_{2}, \mathrm{NO}_{2}$ and $\mathrm{O}_{3}$ had a greater effect on COPD admissions in the cold season (December to March) than during the warm season.

Conclusion: Ambient concentrations of air pollutants have an adverse effect on hospital admissions for COPD in Hong Kong, especially during the winter season. This might be due to indoor exposure to outdoor pollution through open windows as central heating is not required in the mild winter. Measures to improve air quality are urgently needed.
\end{abstract}

A ir pollution is a major public health problem resulting from emissions of air pollutants from both motor vehicles and industrial plants. Previous studies have shown that air pollution is associated with excessive respiratory and cardiovascular morbidity ${ }^{1-8}$ as well as mortality. ${ }^{9-13}$

Hong Kong is a small but densely populated city. The total population was 6.88 million in mid 2004 with a population density of 6380 people per $\mathrm{km}^{2} .{ }^{14}$ Over the past 10 years the air quality in Hong Kong has worsened substantially. The concentrations of particulates with an aerodynamic diameter $<10 \mu \mathrm{m}\left(\mathrm{PM}_{10}\right)$ and ozone $\left(\mathrm{O}_{3}\right)$ recorded at the general air monitoring stations in Hong Kong increased by $15 \%$ and $26 \%$, respectively, from 1999 to $2004 .{ }^{15}$ The level of nitrogen dioxide $\left(\mathrm{NO}_{2}\right)$ also increased by $26 \%$ between 1991 and 2002. ${ }^{16}$ Because of the increase in particulate pollution, impairment in visibility in Hong Kong has also worsened over time. The percentage of time in a year with visibility $<8 \mathrm{~km}$ (with relative humidity $\leqslant 80 \%$ ) increased from $4 \%$ in 1991 to $18 \%$ in $2004 .{ }^{15}$ The major source of air pollutants in Hong Kong is air pollutant emissions from road traffic..$^{5}$ In addition, with increased industrialisation in the southern part of China, pollutants generated by motor vehicles, power plants and various industries in the Pearl River Delta region also contributed to the increasing air pollution in Hong Kong. ${ }^{16}$

Chronic obstructive pulmonary disease (COPD) is an important disease worldwide and acute exacerbations are associated with significant morbidity such as hospitalisations and mortality. ${ }^{17}$ COPD was the fifth leading cause of death in Hong Kong and accounted for at least $4 \%$ of all public hospital acute admissions in 2003. Previous studies have shown that pulmonary function and quality of life are adversely affected by frequent exacerbations, particularly in active smokers. ${ }^{18}{ }^{19} \mathrm{~A}$ study conducted in Hong Kong a decade ago showed that air pollution was associated with a significantly increased risk of hospitalisation for patients with respiratory diseases including acute exacerbations of COPD. ${ }^{5}$ With increasing air pollution, the effect of air pollutants on acute exacerbations of COPD may be enhanced.

As over $90 \%$ of the citizens of Hong Kong are dependent on the public hospital healthcare resources, data on COPD admissions can be retrieved from the central computer system of the Hospital Authority Head Office (HAHO). We assessed the effect of air pollutants-including $\mathrm{NO}_{2}$, sulphur dioxide $\left(\mathrm{SO}_{2}\right)$, $\mathrm{O}_{3}, \mathrm{PM}_{10}$ and particulates with an aerodynamic diameter $<2.5 \mu \mathrm{m}\left(\mathrm{PM}_{2.5}\right)$ - over a period of 5 years (from January 2000 to December 2004) on emergency admission rates of COPD. Data were collected from 15 major hospitals and 14 air quality monitoring stations in Hong Kong over the same period.

\section{METHODS}

This is a retrospective ecological study. Data on emergency hospital admissions for COPD to 15 major hospitals from January 2000 to December 2005 inclusive were obtained from

Abbreviations: APHEA2, Air Pollution and Health: A European Approach 2; COPD, chronic obstructive pulmonary disease; NMMAPS, National Morbidity, Mortality, and Air Pollution Study; $\mathrm{NO}_{2}$, nitrogen dioxide; $\mathrm{O}_{3}$, ozone; $\mathrm{PM}_{10}$, particulates with an aerodynamic diameter $<10 \mu \mathrm{m} ; \mathrm{PM}_{2.5}$, particulates with an aerodynamic diameter $<2.5 \mu \mathrm{m}$; SARS, severe acute respiratory syndrome; $\mathrm{SO}_{2}$, sulphur dioxide 
the HAHO in Hong Kong. The daily number of hospital admissions with the codes 491, 492 and 496, based on the Ninth Revision of the International Classification of Diseases $(\mathrm{ICD}-9)^{20}$ as the primary diagnosis, was recorded.

\section{Air quality and weather data}

Hourly concentrations of $\mathrm{NO}_{2}, \mathrm{SO}_{2}, \mathrm{O}_{3}, \mathrm{PM}_{10}$ and $\mathrm{PM}_{2.5}$ between January 2000 and December 2004 were obtained from the Environmental Protection Department. ${ }^{21}$ The 14 air quality monitoring stations were located in eight districts interspersed in different districts throughout Hong Kong. All the monitoring stations measured levels of $\mathrm{NO}_{2}, \mathrm{SO}_{2}, \mathrm{O}_{3}$ and $\mathrm{PM}_{10}$. However, $\mathrm{PM}_{2.5}$ was measured by three stations only. $\mathrm{SO}_{2}$ was measured by ultraviolet florescence, $\mathrm{NO}_{2}$ by chemiluminescence and $\mathrm{O}_{3}$ by ultraviolet absorption. Both $\mathrm{PM}_{10}$ and $\mathrm{PM}_{2.5}$ were measured by the tapered element oscillating microbalance method. The $24 \mathrm{~h}$ mean concentrations of $\mathrm{NO}_{2}, \mathrm{SO}_{2}, \mathrm{PM}_{10}$ and $\mathrm{PM}_{2.5}$ were calculated. Since the formation of $\mathrm{O}_{3}$ is dependent on sunlight, a daytime (09:00 to 17:00 h) mean concentration was used for analysis. The mean daily temperatures and relative humidity for the same period were obtained from the Hong Kong Observatory.

\section{Statistical modelling}

The statistical model developed from the Air Pollution and Health: A European Approach 2 (APHEA2) protocol for the time series analyses of mortality and hospital admissions in Europe $^{22}$ was used in this study. A generalised additive model ${ }^{23}$
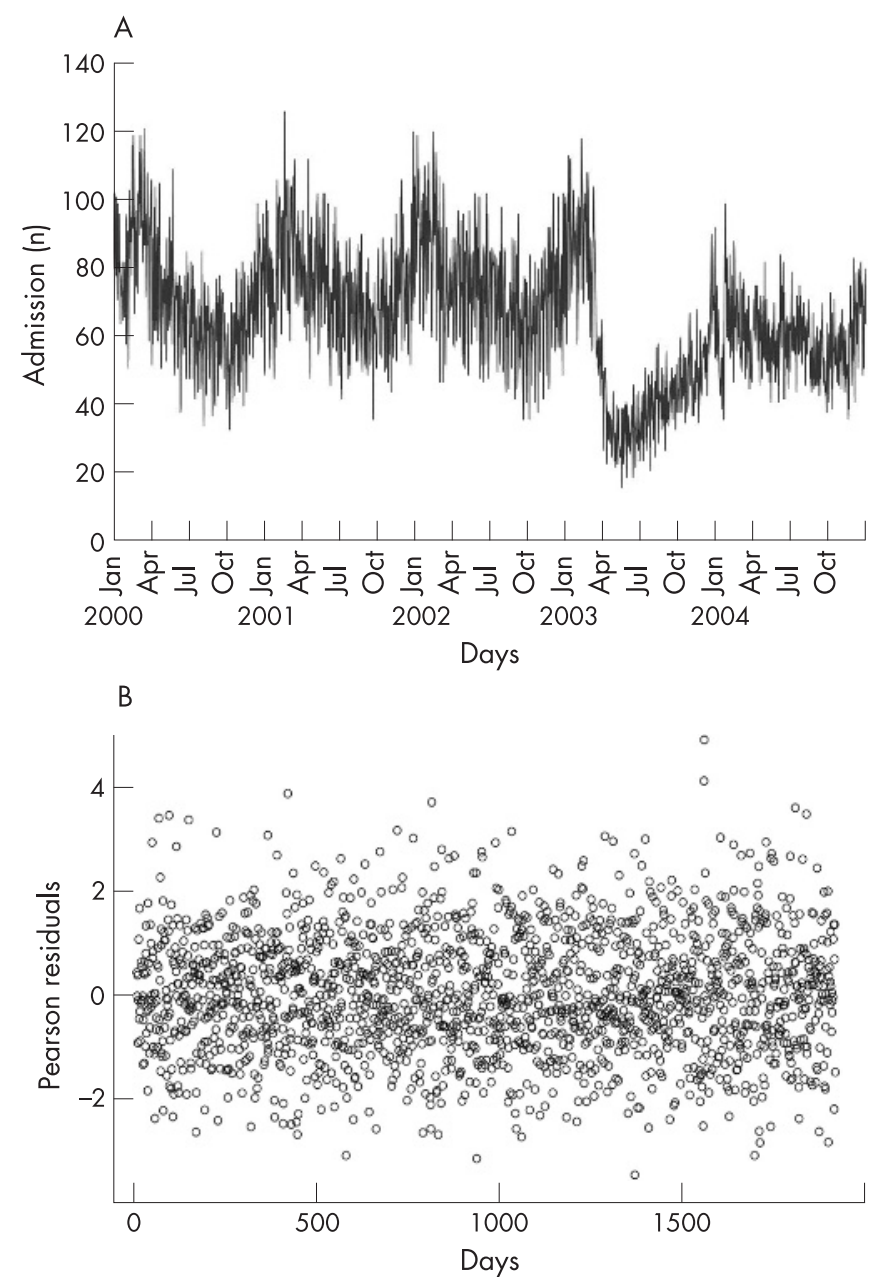

Figure 1 (A) Number of daily admissions for chronic obstructive pulmonary disease (COPD) from January 2000 to December 2004. (B) Time plot of Pearson residuals of daily admissions for respiratory diseases based on the core model. using a Poisson distribution with log-link function was used to construct a core model. This regressed the daily numbers of COPD admissions on the time variable (day), day of the week variable, daily mean temperature and humidity, and holiday indicator. Smoothing of the time variable was used to control for the long-term seasonal patterns of COPD visits and smoothing splines were used as smoothers. The quasi-likelihood method was used to correct for overdispersion. Each core model was chosen based on the degree of freedom that gave the minimum Akaike's information criterion (AIC) value. ${ }^{24}$ Autocorrelation was adjusted by adding autoregressive terms to the model. After controlling for the confounding effects of seasonality, days of the week and climatic variables, daily concentrations of $\mathrm{PM}_{10}, \mathrm{NO}_{2}, \mathrm{SO}_{2}, \mathrm{O}_{3}$ and $\mathrm{PM}_{2.5}$ were added to the core model to determine the relative risk (RR) of COPD admissions for a $10 \mu \mathrm{g} / \mathrm{m}^{3}$ increase in each of these air pollutants. Concentrations of all the air pollutants for the same day (lag 0) up to lag days (lag 5) and cumulative lags by 2 (average of lag 0 and 1), 3 (average of lag 0, 1 and 2) to 6 days (average of lag 0-5) were tested in each model. The lag day with the air pollutant concentration that yielded the largest $\chi^{2}$ value obtained from the change in deviances ${ }^{23}$ was chosen.

Multipollutant models were run for air pollutants that were significant in the single pollutant analysis, and the lag with the strongest univariate effect was tested. The correlation coefficients of the individual air pollutants were examined and only those with $\mathrm{r}<0.7$ were entered into the model. Pairwise analyses were performed by entering each pollutant, cold season indicator and their interaction term into the core model. December to March was considered to be the cold season in Hong Kong with a mean daily temperature below $20^{\circ} \mathrm{C} .^{5}$ The standard errors of the estimates were computed using the supplementary program used in the re-analysis of the National Morbidity, Mortality, and Air Pollution Study (NMMAPS). ${ }^{25}$ All calculations were performed with the software S-plus 4.0 using a more stringent convergence criteria in the gam(.) function to prevent the convergence problem. ${ }^{26}$

\section{RESULTS}

There were 119225 admissions for acute exacerbations of COPD from January 2000 to December 2004 with mean (SD) annual and daily admissions of 23845 (3645) and 65.3 (18.9), respectively. Figure 1 shows a plot of daily admissions over the 5 year period with the Pearson residuals. The seasonal or longterm pattern was not apparent in the residuals.

The means, standard deviations, ranges and percentiles of the daily counts of hospital admissions, daily levels of $\mathrm{NO}_{2}, \mathrm{SO}_{2}$, $\mathrm{PM}_{10}$ and $\mathrm{PM}_{2.5}$ and the levels of $\mathrm{O}_{3}$ from 09:00 to 17:00 h are shown in table 1. Correlations of the pollutants are shown in table 2; a close correlation was found between $\mathrm{PM}_{10}$ and $\mathrm{PM}_{2.5}$ $(\mathrm{r}=0.95, \mathrm{p}<0.001)$.

There was a statistically significant association between hospital admissions for acute exacerbations of COPD and an increase in $10 \mu \mathrm{g} / \mathrm{m}^{3}$ of all five pollutants $\left(\mathrm{NO}_{2}, \mathrm{PM}_{10}, \mathrm{O}_{3}, \mathrm{SO}_{2}\right.$ and $\mathrm{PM}_{2.5}$; table 3 ). A lag effect (cumulative from day 0 to $\geqslant 2$ days) was found for all the pollutants assessed except $\mathrm{SO}_{2}$. The strongest effect on COPD admissions observed for $\mathrm{SO}_{2}$ (RR $1.007,95 \%$ CI 1.001 to 1.014 ) was on lag 0 (ie, no lag days), whereas for $\mathrm{NO}_{2}$ (RR 1.026, 95\% CI 1.022 to 1.031 ) it was on cumulative lag days $0-3$ as indicated by the greatest $\chi^{2}$ score ("best" lag). A more delayed effect on COPD admission was observed for $\mathrm{O}_{3}$ (RR 1.034, 95\% CI 1.030 to 1.040), $\mathrm{PM}_{10}$ (RR $1.024,95 \%$ CI 1.021 to 1.028 ) and $\mathrm{PM}_{2.5}$ (RR $1.031,95 \%$ CI 1.026 to 1.036 ), with the "best" cumulative lag days of $0-5$. The overdispersion parameter $(\phi)$ and the autocorrelation coefficients were 1.295 and -0.02163 , respectively. The intercorrelation between the coefficients $(\beta)$ of the pollutants in the 
Table 1 Daily summary of the number of COPD admissions, meteorological and pollutant data

\begin{tabular}{llllllll}
\hline & Mean & SD & Min & Q1 & Median & Q3 & Max \\
\hline Admissions for COPD $(\mathrm{n})$ & 65.3 & 18.9 & 15 & 52 & 65 & 78 & 125 \\
Temperature ( $\left.{ }^{\circ} \mathrm{C}\right)$ & 23.7 & 4.9 & 8.2 & 19.9 & 25.2 & 27.9 & 31.0 \\
Relative humidity (\%) & 74.4 & 12.8 & 21.1 & 67.6 & 77.0 & 83.0 & 97.0 \\
$\mathrm{NO}_{2}\left(\mu \mathrm{g} / \mathrm{m}^{3}\right)$ & 51.2 & 21.8 & 10.1 & 35.0 & 50.1 & 64.0 & 157.6 \\
$\mathrm{PM}_{10}\left(\mu \mathrm{g} / \mathrm{m}^{3}\right)$ & 50.1 & 23.9 & 13.6 & 31.9 & 44.5 & 64.1 & 172.2 \\
$\mathrm{O}_{3}\left(\mu \mathrm{g} / \mathrm{m}^{3}\right)$ & 31.0 & 16.2 & 4.8 & 18.1 & 26.7 & 41.0 & 101.3 \\
$\mathrm{SO}_{2}\left(\mu \mathrm{g} / \mathrm{m}^{3}\right)$ & 15.0 & 11.6 & 0.7 & 7.6 & 12.5 & 19.5 & 99.4 \\
$\mathrm{PM}_{2.5}\left(\mu \mathrm{g} / \mathrm{m}^{3}\right)$ & 35.7 & 20.6 & 6.0 & 19.4 & 31.7 & 46.7 & 163.2 \\
\hline
\end{tabular}

$\mathrm{SD}$, standard deviation; Q1, 25th percentile; $\mathrm{Q} 3$, 75th percentile; Min, minimum; Max, maximum; COPD, chronic obstructive pulmonary disease; $\mathrm{NO}_{2}$, nitrogen dioxide; $\mathrm{O}_{3}$, ozone; $\mathrm{PM}_{10}, \mathrm{PM}_{2.5}$, particulates with an aerodynamic diameter $<10 \mu \mathrm{m}$ or $<2.5 \mu \mathrm{m} ; \mathrm{SO}_{2}$, sulphur dioxide.

multipollutant model, based on the covariance matrix, ${ }^{25}$ ranged from -0.4161 to 0.2005 .

We noted a sharp fall in the number of daily admissions in April 2003, which was probably due to the major outbreak of severe acute respiratory syndrome (SARS) in Hong Kong at that time. ${ }^{27} 28$ As a sensitivity analysis, we constructed separate models for hospital admissions in 2000-2002, 2003 and 2004 by analysing the data before, during and after the SARS epidemic in 2003. The RRs before 2003 were lower than those after 2003 for $\mathrm{NO}_{2}, \mathrm{O}_{3}, \mathrm{PM}_{10}$ and $\mathrm{PM}_{2.5}$, but the results were largely similar to those when the entire period was used for the model (data available in supplemental table 1 available online at www.thorax.bmj.com/supplemental).

The multipollutant model was constructed and the results are shown in table $4 . \mathrm{SO}_{2}, \mathrm{O}_{3}$ and $\mathrm{PM}_{2.5}$ were statistically most significantly related to COPD admissions. Of all the pollutants, $\mathrm{O}_{3}$ had the highest $\chi^{2}$ score, indicating that it contributed to the greatest risk of admission for COPD (RR 1.029, 95\% CI 1.022 to 1.036). There was only moderate correlation $(\mathrm{r}<0.5)$ between most air pollutants, except for the correlations between $\mathrm{NO}_{2}$ and $\mathrm{SO}_{2}(\mathrm{r}=0.66)$ and between $\mathrm{PM}_{2.5}$ and $\mathrm{PM}_{10}(\mathrm{r}>0.9)$. Since $\mathrm{PM}_{2.5}$ is widely believed to be more damaging to health and has a higher RR for admission to hospital with an acute exacerbation of COPD than $\mathrm{PM}_{10}$, the former was selected into the statistical model instead.

There was also a seasonal effect on the air pollutants. Using $20^{\circ} \mathrm{C}$ as the cut-off temperature, a lower temperature was associated with a higher level of mean daily $\mathrm{PM}_{10}, \mathrm{PM}_{2.5}$ and $\mathrm{NO}_{2}$ but a lower level of mean $8 \mathrm{~h} \mathrm{O}_{3}$. In addition, the mean number of daily admissions was higher with a lower temperature ( 74.5 vs $61.9, \mathrm{p}<0.0001)$. The interaction between seasons and individual pollutants is shown in table 5. An additive effect of the cold weather on the pollutants was observed on COPD admissions for $\mathrm{NO}_{2}, \mathrm{O}_{3}$ and $\mathrm{SO}_{2}$ (RR 1.016
(95\% CI 1.009 to 1.024$), 1.020$ (95\% CI 1.008 to 1.031 ) and 1.0201 (95\% CI 1.008 to 1.033 ), respectively).

\section{DISCUSSION}

This study assessed the effects of air pollution specifically on hospital admissions for acute exacerbations of COPD. All five air pollutants $\left(\mathrm{NO}_{2}, \mathrm{SO}_{2}, \mathrm{O}_{3}, \mathrm{PM}_{10}\right.$ and $\left.\mathrm{PM}_{2.5}\right)$ had a positive association with hospital admissions for acute exacerbations of COPD, with different magnitudes in terms of the relative risks and the number of lag days. Previous time series studies in Asia did not focus on COPD alone but on admissions for all respiratory diseases or all-cause mortality. ${ }^{5}{ }^{10}{ }^{11}$ As the time frame chosen in this study was recent and for an extended duration (from January 2000 to December 2004), this study provides up to date information on the effects of air pollutants specifically on COPD.

The total number of hospital admissions in this single-city study was high $(n=119225)$ when compared with other US national multi-city studies; for example, a US multi-city study by Medina-Ramon et al included a total of 578006 admissions. ${ }^{2}$ As there was a sharp decline in the number of daily admissions in April 2003 which was most probably caused by the major outbreak of SARS, ${ }^{27} 28$ we constructed separate models to analyse hospital admissions and air pollution data for the periods before, during and after the SARS epidemic in 2003. Although the RRs before 2003 were lower than those after 2003 for $\mathrm{NO}_{2}, \mathrm{O}_{3}, \mathrm{PM}_{10}$ and $\mathrm{PM}_{2.5}$, the results were similar to those when the entire period was used for the model. Not only has this confirmed the robustness of the general additive model in correcting for the potential effects caused by an epidemic that might affect the number of hospital admissions, it has shown that the relationship between air pollution and COPD admissions was not affected by an event that reduced hospital admissions but not air pollution.

Table 2 Correlations between different air pollutants and meteorological variables

\begin{tabular}{|c|c|c|c|c|c|c|c|c|}
\hline & & $\mathrm{SO}_{2}$ & $\mathrm{NO}_{2}$ & $\mathrm{PM}_{10}$ & $\mathrm{O}_{3}$ & $\mathrm{PM}_{2.5}$ & Temperature & Humidity \\
\hline \multirow[t]{2}{*}{$\mathrm{SO}_{2}$} & $r$ & 1.00 & $0.659 *$ & $0.229 *$ & $-0.037^{*}$ & 0.282 & $0.084^{*}$ & $0.169^{*}$ \\
\hline & $p$ value & - & $<0.001$ & $<0.001$ & 0.111 & $<0.001$ & $<0.001$ & $<0.001$ \\
\hline \multirow[t]{2}{*}{$\mathrm{NO}_{2}$} & $\mathrm{r}$ & & 1.00 & $0.399^{*}$ & $0.338^{*}$ & 0.441 & $-0.268^{*}$ & $0.212^{*}$ \\
\hline & $p$ value & & - & $<0.001$ & $<0.001$ & $<0.001$ & $<0.001$ & $<0.001$ \\
\hline \multirow[t]{2}{*}{$\mathrm{PM}_{10}$} & r & & & 1.00 & $0.421^{*}$ & 0.952 & $-0.344^{*}$ & $-0.390^{*}$ \\
\hline & $p$ value & & & - & $<0.001$ & $<0.001$ & $<0.001$ & $<0.001$ \\
\hline \multirow[t]{2}{*}{$\mathrm{O}_{3}$} & r & & & & 1.00 & 0.394 & -0.028 & $-0.106^{*}$ \\
\hline & $p$ value & & & & - & $<0.001$ & 0.236 & $<0.001$ \\
\hline \multirow[t]{2}{*}{$\mathrm{PM}_{2.5}$} & $r$ & & & & & 1.00 & -0.356 & -0.343 \\
\hline & $p$ value & & & & & - & $<0.001$ & $<0.001$ \\
\hline \multirow[t]{2}{*}{ Temperature } & $r$ & & & & & & 1.00 & $0.127^{*}$ \\
\hline & $p$ value & & & & & & - & 0.001 \\
\hline \multirow{2}{*}{ Humidity } & r & & & & & & & 1.00 \\
\hline & $p$ value & & & & & & & - \\
\hline
\end{tabular}

$r$, Pearson correlation coefficient; $\mathrm{SO}_{2}$, sulphur dioxide; $\mathrm{NO}_{2}$, nitrogen dioxide; $\mathrm{O}_{3}$, ozone; $\mathrm{PM}_{10}$, $\mathrm{PM} 2.5$, particulates with an aerodynamic diameter $<10 \mu \mathrm{m}$ or $<2.5 \mu \mathrm{m}$. 
Table 3 Relative risk (with $95 \% \mathrm{Cl}$ ) for the pollutants per $10 \mu \mathrm{g} / \mathrm{m}^{3}$ increase in the concentration of air pollutants for hospitalisations due to an acute exacerbation of COPD (single pollutant model)

\begin{tabular}{|c|c|c|c|c|c|}
\hline Lag days & $\mathrm{NO}_{2}$ & $\mathrm{PM}_{10}$ & $\mathrm{O}_{3}(8 \mathrm{~h})$ & $\mathrm{SO}_{2}$ & $\mathrm{PM}_{2.5}$ \\
\hline $\operatorname{Lag} 0$ & 1.009 (1.005 to 1.013$)^{* *}$ & $1.003(1.000 \text { to } 1.005)^{*}$ & 1.002 (0.998 to 1.005 ) & $1.007(1.001 \text { to } 1.014)^{*} \dagger$ & 1.002 (0.998 to 1.001$)$ \\
\hline $\operatorname{Lag} 1$ & 1.001 (0.997 to 1.005$)$ & 1.005 (1.002 to 1.007$)^{\star *}$ & 1.011 (1.008 to 1.015$)^{* *}$ & 0.991 (0.981 to 1.001$)$ & $1.003(0.999 \text { to } 1.007)^{* *}$ \\
\hline Lag 2 & 1.003 (0.999 to 1.007 ) & $1.010(1.007 \text { to } 1.012)^{* \star}$ & $1.011(1.008 \text { to } 1.020)^{* *}$ & $0.992(0.985$ to 1.000$)$ & $1.011(1.007 \text { to } 1.014)^{\star *}$ \\
\hline $\operatorname{Lag} 3$ & $1.010(1.007 \text { to } 1.014)^{\star *}$ & $1.011(1.008 \text { to } 1.013)^{\star *}$ & 1.011 (1.012 to 1.019$)^{\star *}$ & 1.006 (0.999 to 1.013 ) & $1.013(1.010 \text { to } 1.017)^{* *}$ \\
\hline $\operatorname{Lag} 4$ & $1.010(1.007 \text { to } 1.014)^{* *}$ & $1.008(1.006 \text { to } 1.011)^{* *}$ & 1.011 (1.008 to 1.015$)^{* *}$ & 1.004 (0.998 to 1.011$)$ & $1.011(1.008 \text { to } 1.015)^{* *}$ \\
\hline Lag 5 & 1.008 (1.004 to 1.012$)^{\star \star *}$ & $1.007(1.004 \text { to } 1.009)^{* *}$ & 1.006 (1.003 to 1.010$)^{* *}$ & 1.004 (0.997 to 1.010$)$ & $1.009(1.006 \text { to } 1.013)^{* *}$ \\
\hline $\operatorname{Lag} 0-1$ & $1.007(1.003 \text { to } 1.011)^{\star \star}$ & $1.005(1.002 \text { to } 1008)^{\star *}$ & $1.011(1.006 \text { to } 1.014)^{\star \star}$ & 0.998 (0.991 to 1.006$)$ & 1.004 (0.999 to 1.008 ) \\
\hline Lag 0-2 & $1.009(1.004 \text { to } 1.013)^{* *}$ & 1.011 (1.008 to 1.014$)^{* *}$ & $1.019(1.015 \text { to } 1.023)^{* *}$ & 0.993 (0.985 to 1.001$)$ & $1.010(1.006 \text { to } 1.015)^{* *}$ \\
\hline Lag 0-3 & $1.026(1.022 \text { to } 1.031)^{* \star} \dagger$ & 1.016 (1.013 to 1.019$)^{* *}$ & $1.027(1.02 \text { to } 1.031)^{* *}$ & 0.998 (0.989 to 1.007 ) & $1.018(1.013 \text { to } 1.022)^{* *}$ \\
\hline $\operatorname{Lag} 0-4$ & 1.021 (1.017 to 1.026$)^{* *}$ & 1.020 (1.017 to 1.024 ) & $1.031(1.027 \text { to } 1.036)^{* *}$ & 1.001 (0.991 to 1.010$)$ & 1.024 (1.019 to 1.029$)^{* *}$ \\
\hline Lag 0-5 & $1.026(1.022 \text { to } 1.031)^{* \star}$ & 1.024 (1.021 to 1.028$)^{* *} \dagger$ & $1.034(1.030 \text { to } 1.040)^{* *} \dagger$ & 1.004 (0.994 to 1.014$)$ & $1.031(1.026 \text { to } 1.036)^{* \star} \dagger$ \\
\hline
\end{tabular}

$\mathrm{SO}_{2}$, sulphur dioxide; $\mathrm{NO}_{2}$, nitrogen dioxide; $\mathrm{O}_{3}$, ozone; $\mathrm{PM}_{10}, \mathrm{PM}_{2.5}$, particulates with an aerodynamic diameter $<10 \mu \mathrm{m}$ or $<2.5 \mu \mathrm{m}$.

${ }^{*} \mathrm{p}<0.05,{ }^{* *} \mathrm{p}<0.001$.

†Highest $\chi^{2}$ score (best lag).

The concentrations of $\mathrm{PM}_{10}$ and $\mathrm{PM}_{2.5}$ in Hong Kong were high in 2000-4 compared with other western countries. The mean (SD) level of $\mathrm{PM}_{10}$ was $50.1(23.9) \mu \mathrm{g} / \mathrm{m}^{3}$ in the current study, compared with a level of $30.4(5.1) \mu \mathrm{g} / \mathrm{m}^{3}$ in a study involving 36 American cities ${ }^{2}$ in 1986-99. Our median level of $\mathrm{PM}_{10}\left(44.5 \mu \mathrm{g} / \mathrm{m}^{3}\right)$ was also higher than those in several European studies (median levels for Stockholm, Birmingham, London and Netherlands 13.6, 21.5, 24.9 and $33.4 \mu \mathrm{g} / \mathrm{m}^{3}$, respectively). For $\mathrm{PM}_{2.5}$, the median (IQR) level in this current study was $31.7(19.4-46.7) \mu \mathrm{g} / \mathrm{m}^{3}$, which was much higher than the level of $13.4(11.3-15.2) \mu \mathrm{g} / \mathrm{m}^{3}$ in a national US study. ${ }^{1}$ Our study had comparable levels of $\mathrm{SO}_{2}, \mathrm{O}_{3}$ and $\mathrm{NO}_{2}$ to those in western European cities such as Rome. ${ }^{7}$

We found that a $10 \mu \mathrm{g} / \mathrm{m}^{3}$ increase in $\mathrm{PM}_{10}$ was associated with a $2.4 \%$ increase in hospital admissions for acute exacerbations of COPD at cumulative lag days of $0-5$. The effect of $\mathrm{PM}_{10}$ on respiratory admissions appeared to be less than in other studies. For example, in the NMMAPS, which focused on the 20 largest metropolitan areas in the USA in 1987-94, every $10 \mu \mathrm{g} / \mathrm{m}^{3}$ increase in $\mathrm{PM}_{10}$ level was associated with an increase in hospital admissions for COPD of $1.5 \%$ (range 1.0-1.9\%). ${ }^{30-32}$ The NMMAPS statistical model is overspecified with regard to long-wave controlling variables for season and weather placed in the model (along with the pollution) relative to the more generally accepted methods published in the literature..$^{25} 34$ This has apparently led to smaller estimates of pollution effects in publications deriving from the NMMAPS study, and the difference in estimates can be up to twofold..$^{34}$ Indeed, we have found that, by applying the more aggressive adjustment NMMAPS model, the effects of $\mathrm{PM}_{10}, \mathrm{NO}_{2}, \mathrm{O}_{3}$ and $\mathrm{PM}_{2.5}$ on COPD admissions were of smaller magnitudes than the APHEA2 statistical model. Our observations of underestimation of pollution effects with the NMMAPS model were similar to the those reported by Schwartz et $a^{33}$ and Ito et al. ${ }^{34}$ The APHEA2 study, which assessed hospital admissions in eight European cities in the mid 1990s, found an increase of $1.0 \%$ (range $0.4-1.5 \%$ ) per $10 \mu \mathrm{g} / \mathrm{m}^{3}$ increase in
$\mathrm{PM}_{10}$ level in asthma and COPD admissions among people aged $>65$ years. However, COPD was not assessed separately in the APHEA2 study. ${ }^{6}$ Our results showed that the effect of $\mathrm{PM}_{10}$ on hospital admissions with COPD was similar to that reported in the NMMAPS study, ${ }^{30-32}$ based on the same method of analysis. The effect of $\mathrm{PM}_{10}$ on combined COPD and asthma hospitalisations in Europe in the APHEA2 study ${ }^{6}$ was of lesser magnitude than in our study.

The high $\mathrm{PM}_{2.5}$ level in our study was associated with a higher impact on COPD admissions than in other studies. A $10 \mu \mathrm{g} / \mathrm{m}^{3}$ increase in $\mathrm{PM}_{2.5}$ was associated with a $3.1 \%$ increase in COPD admissions with a cumulative lag of $0-5$ in our study using the APHEA2 statistical model, in contrast to a recent US study using the NMMAPS statistical model which found the largest effect per $10 \mu \mathrm{g} / \mathrm{m}^{3}$ increase in $\mathrm{PM}_{2.5}$ occurring at lag 0 and 1 with a risk of about $0.9 \% .{ }^{1}$ Analysis of our data using the NMMAPS model has shown that each $10 \mu \mathrm{g} / \mathrm{m}^{3}$ increase in $\mathrm{PM}_{2.5}$ was associated with a $2.0 \%$ increase in COPD admissions, and the effect of $\mathrm{PM}_{2.5}$ was higher than that reported by Dominici et al. ${ }^{1}$ The higher impact of the $\mathrm{PM}_{2.5}$ level on respiratory admissions as noted in our study may be due to a higher level of $\mathrm{PM}_{2.5}$ in our community and a dose-response effect of the pollutants on respiratory morbidity. The effect of particulate matter on respiratory morbidity remains a focus of research. The leading hypothesis emphasised inflammatory responses in the lungs and release of cytokines with local and systemic consequences. Particulate matters may promote inflammation, thereby exacerbating underlying lung diseases and reducing the efficacy of lung defence mechanisms. ${ }^{12}{ }^{35}$

Despite several previous reports from Hong Kong on increasing air pollution, ${ }^{15}{ }^{16}$ the average values detected by the air quality monitoring stations for $\mathrm{NO}_{2}, \mathrm{SO}_{2}, \mathrm{O}_{3}$ and $\mathrm{PM}_{10}$ did not differ significantly from a previous study conducted by Wong et $a l^{5}$ in Hong Kong in 1994-5 on the effect of air pollutants on all respiratory admissions. In fact, the effect of individual pollutants on COPD in our study was similar to that in the study by Wong et al. ${ }^{5}$ However, the cumulative effect of

Table 4 Relative risk (with $95 \% \mathrm{Cl}$ ) for the pollutants per $10 \mu \mathrm{g} / \mathrm{m}^{3}$ increase in the concentration of air pollutants for hospitalisations due to an acute exacerbation of COPD (multipollutant model)

\begin{tabular}{lllll}
\hline & $\begin{array}{l}\mathrm{NO}_{2} \\
(\operatorname{lag} 0-3)\end{array}$ & $\begin{array}{l}\mathrm{O}_{3}(8 \mathrm{~h}) \\
(\operatorname{lag} 0-5)\end{array}$ & $\begin{array}{l}\mathrm{SO}_{2} \\
(\operatorname{lag} 0)\end{array}$ & $\begin{array}{l}\mathrm{PM}_{2.5} \\
(\operatorname{lag} 0-5)\end{array}$ \\
\hline $\begin{array}{l}4 \text { pollutant model } \\
3 \text { pollutant model }\end{array}$ & $0.993(0.985$ to 1.001) & $1.029(1.022 \text { to } 1.036)^{*} \dagger$ & $1.008(1.001 \text { to } 1.015)^{*}$ & $\begin{array}{l}1.014(1.007 \text { to } 1.022)^{*} \\
1.011(1.004 \text { to } 1.017)^{*}\end{array}$ \\
\hline
\end{tabular}

$\mathrm{SO}_{2}$, sulphur dioxide; $\mathrm{NO}_{2}$, nitrogen dioxide; $\mathrm{O}_{3}$, ozone; $\mathrm{PM}_{10}, \mathrm{PM}_{2.5}$, particulates with an aerodynamic diameter $<10 \mu \mathrm{m}$ or $<2.5 \mu \mathrm{m}$. ${ }^{*} \mathrm{p}<0.05$.

†Highest $\chi^{2}$ score in the pollutant model. 
Table 5 Interaction between season and individual pollutants

\begin{tabular}{lllcl}
\hline Pollutant & RR & $95 \% \mathrm{Cl}$ & p Value & t Score \\
\hline $\mathrm{NO}_{2}$ (lag 0-3) & 1.0164 & 1.0086 to 1.0243 & $<0.0001^{*}$ & 4.150476 \\
$\mathrm{O}_{3}$ (lag 0-5) & 1.0195 & 1.0081 to 1.0309 & $0.0007^{*}$ & 3.379242 \\
$\mathrm{SO}_{2}$ (lag 0) & 1.0205 & 1.0078 to 1.0334 & $0.0015^{*}$ & 3.178459 \\
$\mathrm{PM}_{2.5}$ (lag 0-5) & 0.9983 & 0.9891 to 1.0076 & 0.5200 & 0.643313 \\
$\mathrm{PM}_{10}$ (lag 0-3) & 1.0012 & 0.9951 to 1.0073 & 0.7059 & 0.37738 \\
\hline
\end{tabular}

RR, relative risk (the warm season was used as the reference). The cold season is defined as the period from December to March of each year.

${ }^{*} \mathrm{p}<0.05$.

$\mathrm{NO}_{2}, \mathrm{SO}_{2}$ and $\mathrm{PM}_{10}$ was assessed only for up to 4 days (lag 0-3) by Wong et al, whereas we have extended the cumulative lag to 6 days (lag 0-5) for all the pollutants. We noted the most statistically significant effect of $\mathrm{PM}_{10}$ on COPD admissions was at lag $0-5$, in contrast to lag $0-3$ in the study by Wong et al. ${ }^{5}$ Concerning the use of cumulative lags in analysing the effects of pollutants on admissions for COPD, the RRs derived from two different averaging period variables must be interpreted with caution. For example, it requires a longer duration of exposure to effect a change of $1 \mu \mathrm{g} / \mathrm{m}^{3}$ in a 5 day average (ie, a $1 \mu \mathrm{g} / \mathrm{m}^{3}$ increase on 5 consecutive days) than for a 1 day average increase of $1 \mu \mathrm{g} / \mathrm{m}^{3}$ (ie, a l day increase of $1 \mu \mathrm{g} / \mathrm{m}^{3}$ on a single day only). Our study has provided additional information on the effect of $\mathrm{PM}_{2.5}$ on COPD admissions which was not addressed in the previous study. ${ }^{5}$ Furthermore, a multipollutant model specific for acute exacerbations of COPD was not constructed in the study by Wong et al. ${ }^{5}$ In our study, when a number of pollutants $\left(\mathrm{NO}_{2}, \mathrm{SO}_{2}, \mathrm{O}_{3}\right.$ and $\left.\mathrm{PM}_{2.5}\right)$ were analysed together, all except $\mathrm{NO}_{2}$ were retained in the model. As expected, the RRs of the individual pollutants were smaller than those in the single pollutant models, with $\mathrm{O}_{3}$ having the greatest effect on COPD admissions.

We found differences in the maximum effect of the individual air pollutants on COPD hospitalisations in terms of the number of cumulative lag days. Despite the use of the "best" lag calculated according to statistical criteria, these differences could possibly be explained by the chemical and toxicological properties of the individual pollutants on the airway. $\mathrm{SO}_{2}$ is very soluble in the upper respiratory tract ${ }^{5}$ and thus may produce an immediate irritant effect on the respiratory mucosa which would account for the fact that no lag days were observed for $\mathrm{SO}_{2}$. In contrast, $\mathrm{O}_{3}$ and $\mathrm{NO}_{2}$ are much less soluble, enabling them to penetrate deeply into the lungs. In addition, these two gaseous pollutants and $\mathrm{PM}_{10}$ are highly reactive oxidants and can cause inflammation of the respiratory epithelium at high concentrations. ${ }^{36-38}$ An experimental chamber exposure study reported a decrease in lung function after exposure to $\mathrm{O}_{3}{ }^{39}$ On the other hand, exposure to $\mathrm{NO}_{2}$ might enhance the recruitment of macrophages and $\mathrm{T}$ lymphocytes to the airway, as shown by increased CD45RO+ lymphocytes, B cells and natural killer (NK) cells in the bronchoalveolar lavage fluid of healthy volunteers. ${ }^{40}$ As oxidant-induced airway inflammation takes time to develop, this may account for some cumulative lag days with $\mathrm{O}_{3}, \mathrm{NO}_{2}$ and $\mathrm{PM}_{10}$ rather than an immediate effect on admissions for acute exacerbations of COPD.

In contrast to this current study, previous studies found an increased risk of admissions for respiratory diseases, including COPD and pneumonia, associated with ambient $\mathrm{O}_{3}$ and $\mathrm{PM}_{10}$ levels predominantly in the warm season. ${ }^{2}{ }^{41}{ }^{42}$ A previous study in the US suggested that the difference in the positive effect of $\mathrm{O}_{3}$ on respiratory admissions in different seasons might be due to higher $\mathrm{O}_{3}$ concentrations and more time spent outdoors during the warm season. Since $\mathrm{O}_{3}$ is a highly reactive gas, its indoor concentration is extremely low in buildings with closed windows. ${ }^{2}$ In Hong Kong the situation differs from western countries as the winter season is not cold enough to require central heating in most places. Windows are often opened in winter for ventilation purposes. Summers are generally hot and humid, and most people spend more time indoors with air conditioning. This might explain the enhanced effects of $\mathrm{O}_{3}$ exposure-and probably $\mathrm{SO}_{2}$ and $\mathrm{NO}_{2}$ exposure-in patients with COPD in the winter in HK. This is supported by a previous study showing that air conditioned homes had lower air exchange rates than homes with windows opened for ventilation. ${ }^{43}$ The reason for the seasonal differences observed in our current study compared with other western studies is not entirely clear and requires further study.

This study has a few limitations. As with other ecological studies, it was limited by the fact that precise exposure to a specific pollutant could not be assessed. Also, the ICD coding for identifying COPD hospital admissions might be limited by the accuracy of coding. In addition, the interaction between pollutants with the collinearity issues and limitations of the time series design made it difficult to assess which particular pollutant had a direct adverse effect on the patients.

In summary, air pollutant levels of $\mathrm{SO}_{2}, \mathrm{NO}_{2}, \mathrm{O}_{3}, \mathrm{PM}_{10}$ and $\mathrm{PM}_{2.5}$ were all associated with increased hospital admissions for acute exacerbations of COPD in Hong Kong. $\mathrm{O}_{3}$ was the most important air pollutant leading to increased hospitalisations for acute exacerbations of COPD, and $\mathrm{PM}_{10}$ and $\mathrm{PM}_{2.5}$ levels in Hong Kong were higher than in other countries. The $\mathrm{PM}_{10}$ concentration exceeded the European Union recommendation (average $24 \mathrm{~h}$ concentration $<40 \mu \mathrm{g} / \mathrm{m}^{3}$ by 2005). ${ }^{32}$ Public health measures are urgently needed to improve air quality in Hong Kong.

\section{ACKNOWLEDGEMENTS}

The authors thank the Environmental Protection Society of Hong Kong for providing the air pollutant data and Mrs Edwina Shung of the Hospital Authority for advice on using health service data.

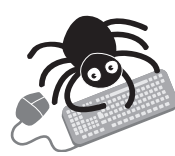

Further data are given in the online supplement available at www.thorax.bmj.com/supplemental
Authors' affiliations
Fanny W S Ko, Doris P S Chan, Alvin H Tung, Christopher K W Lai, David S C Hui, Department of Medicine and Therapeutics, The Chinese University of Hong Kong, Prince of Wales Hospital, Hong Kong
Wilson Tam, Nethersole School of Nursing, The Chinese University of Hong Kong, Prince of Wales Hospital, Hong Kong
Tze Wai Wong, Department of Community and Family Medicine, The Chinese University of Hong Kong, Prince of Wales Hospital, Hong Kong Funding: None.
Competing interests: None. 


\section{REFERENCES}

1 Dominici F, Peng RD, Bell ML, et al. Fine particulate air pollution and hospital admission for cardiovascular and respiratory diseases. JAMA 2006;295: 1127-34.

2 Medina-Ramon M, Zanobetti A, Schwartz J. The effect of ozone and $\mathrm{PM}_{10}$ on hospital admissions for pneumonia and chronic obstructive pulmonary disease: a national multicity study. Am J Epidemiol 2006;163:579-88.

3 Wellenius GA, Schwartz J, Mittleman MA. Particulate air pollution and hospital admissions for congestive heart failure in seven United States cities. Am J Cardiol 2006;97:404-8.

4 Arena VC, Mazumdar S, Zborowski JV, et al. A retrospective investigation of $\mathrm{PM}_{10}$ in ambient air and cardiopulmonary hospital admissions in Allegheny County, Pennsylvania: 1995-2000. J Occup Environ Med 2006;48:38-47.

5 Wong TW, Lau TS, Yu TS, et al. Air pollution and hospital admissions for respiratory and cardiovascular diseases in Hong Kong. Occup Environ Med 1999;56:679-83

6 Atkinson RW, Anderson HR, Sunyer J, et al. Acute effects of particulate air pollution on respiratory admissions: results from APHEA 2 project. Air Pollution and Health: a European Approach, Am J Respir Crit Care Med $2001 ; 164: 1860-6$.

7 Fusco D, Forastiere F, Michelozzi $\mathrm{P}$, et al. Air pollution and hospital admissions for respiratory conditions in Rome, Italy. Eur Respir J 2001;17:1 143-50.

8 Wong GW, Ko FW, Lau TS, et al. Temporal relationship between air pollution and hospital admissions for asthmatic children in Hong Kong. Clin Exp Allergy 2001;31:565-9.

9 Ostro B, Broadwin R, Green S, et al. Fine particulate air pollution and mortality in nine California counties: results from CALFINE. Environ Health Perspect 2006;114:29-33.

10 Wong TW, Tam WS, Yu TS, et al. Associations between daily mortalities from respiratory and cardiovascular diseases and air pollution in Hong Kong, China. Occup Environ Med 2002;59:30-5.

11 Kan H, Chen B. Air pollution and daily mortality in Shanghai: a time-series study. Arch Environ Health 2003;58:360-7.

12 Pope CA 3rd, Burnett RT, Thurston GD, et al. Cardiovascular mortality and longterm exposure to particulate air pollution: epidemiological evidence of general pathophysiological pathways of disease. Circulation 2004;109:71-7.

13 Fischer P, Hoek G, Brunekreef B, et al. Air pollution and mortality in The Netherlands: are the elderly more at risk? Eur Respir J Suppl 2003:40:34-8s.

14 Hong Kong Special Administrative Region of the People's Republic of China http://www.info.gov.hk/info/hkbrief/eng/ahk.htm, 2006.

15 Environmental Protection Society of Hong Kong. Improving the air quality in Hong Kong. A progress report, 2005.http://www.epd.gov.hk/epd/english/ environmentinhk/air/prob_solutions/files/Brief_Progress_Report_Nov2005.pdf

16 Environmental Protection Society of Hong Kong. Study of air quality in the Pearl River Delta region, Agreement No. CE 106/98, 2002: ES1-7, http:// www.epd.gov.hk/epd/english/environmentinhk/air/studyrpts/ study_pearl.html.

17 National Heart, Lung and Blood Institute, World Health Organization. Global Initiative for chronic obstructive lung disease. Global strategy for the diagnosis, management and prevention of chronic obstructive pulmonary disease, Updated, 2005.

18 Seemungal TA, Donaldson GC, Paul EA, et al. Effect of exacerbation on quality of life in patients with chronic obstructive pulmonary disease. Am J Respir Crit Care Med 1998;157:1418-22.

19 Donaldson GC, Seemungal TA, Bhowmik A, et al. Relationship between exacerbation frequency and lung function decline in chronic obstructive pulmonary disease. Thorax 2002;57:847-52.

20 World Heath Organisation. International classification of diseases, 1975 revision. Geneva: World Health Organisation, 1977.
21 Environmental Protection Department, The Government of the Special Administration of Hong Kong. Air quality in Hong Kong 2004, http:// www.epd-asg.gov.hk/english/report/files/aqr04e.pdf.

22 Katsouyanni K, Touloumi G, Samoli E, et al. Confounding and effect modification in the short-term effects of ambient particles on total mortality: results from 29 European cities within the APHEA2 project. Epidemiology $2001 ; 12: 521-31$

23 Hastie T, Tibshirani R. Generalized additive models. London: Chapman and Hall, 1990.

24 Hastie T, Tibshirani R. Generalized additive models for medical research. Stat Method's Med Res 1995;4:187-96.

25 NMMAPS data R package. National Mortality, Morbidity, and Air Pollution Study, http://www.ihapss.jhsph.edu/data/NMMAPS/R/.

26 Katsouyanni K, Touloumi G, Samoli E, et al. Different convergence parameters applied to the S-PLUS GAM function. Epidemiology 2002;13:742-3.

27 Hui DS, Sung JJ. Severe acute respiratory syndrome. Chest 2003;124:12-5.

28 Lee $\mathrm{N}$, Hui D, Wu A, et al. A major outbreak of severe acute respiratory syndrome in Hong Kong. N Engl J Med 2003;348:1986-94.

29 Xu X, Gao J, Dockery DW, et al. Air pollution and daily mortality in residential areas of Beijing, China. Arch Environ Health 1994;49:216-22.

30 Samet JM, Dominici F, Curriero FC, et al. Fine particulate air pollution and mortality in 20 U.S. cities, 1987-1994. N Engl J Med 2000;343:1742-9.

31 Samet JM, Zeger SL, Dominici F, et al. The National Morbidity, Mortality, and Air Pollution Study. Part II: Morbidity and mortality from air pollution in the United States. Res Rep Health Eff Inst 2000;94:5-79.

32 Brunekreef B, Holgate ST. Air pollution and health. Lancet 2002;360:1233-42.

33 Schwartz J. Is the association of airborne particles with daily deaths confounded by gaseous air pollutants? An approach to control by matching. Environ Health Perspect 2004; 112:557-61

34 Ito K, De Leon SF, Lippmann M. Associations between ozone and daily mortality: analysis and meta-analysis. Epidemiology 2005;16:446-57.

35 National Research Council Committee on Research Priorities for Airborne Particulate Matter. Research priorities for airborne particulate matter IV: Continuing research progress. Washington, DC: National Academies Press, 2004

36 Corradi M, Alinovi R, Goldoni M, et al. Biomarkers of oxidative stress after controlled human exposure to ozone. Toxicol Lett 2002;134:219-25.

37 Bayram H, Sapsford RJ, Abdelaziz MM, et al. Effect of ozone and nitrogen dioxide on the release of proinflammatory mediators from bronchial epithelial cells of nonatopic nonasthmatic subjects and atopic asthmatic patients in vitro. J Allergy Clin Immunol 2001;107:287-94.

38 Gilmour PS, Rahman I, Donaldson K, et al. Histone acetylation regulates epithelial IL-8 release mediated by oxidative stress from environmental particles. Am J Physiol Lung Cell Mol Physiol 2003;284:L533-40.

39 McDonnell WF, Stewart PW, Andreoni S, et al. Prediction of ozone-induced FEV changes. Effects of concentration, duration, and ventilation. Am J Respir Crit Care Med 1997; 156:715-22.

40 Blomberg A, Krishna MT, Bocchino V, et al. The inflammatory effects of 2 ppm $\mathrm{NO}_{2}$ on the airways of healthy subjects. Am J Respir Crit Care Med 1997; 156:418-24.

41 Burnett RT, Brook JR, Yung WT, et al. Association between ozone and hospitalization for respiratory diseases in 16 Canadian cities. Environ Res 1997;72:24-31.

42 Anderson HR, Spix C, Medina S, et al. Air pollution and daily admissions for chronic obstructive pulmonary disease in 6 European cities: results from the APHEA project. Eur Respir J 1997;10:1064-71.

43 Wallace L. Indoor particles: a review. J Air Waste Manag Assoc 1996:46:98-126

Let us assisł you in teaching the nexł generation

Figures from all articles on our website can be downloaded as a PowerPoint slide. This feature is ideal for teaching and saves you valuable time. Just click on the image you need and choose the "PowerPoint Slide for Teaching" option. Save the slide to your hard drive and it is ready to go. This innovative function is an important aid to any clinician, and is completely free to subscribers. (Usual copyright conditions apply.) 